\title{
PENGARUH MODEL PEMBELAJARAN KOOPERATIF TIPE THINK PAIR SHARE TERHADAP KETERAMPILAN SOSIAL DAN PRESTASI BELAJAR SISWA SMP
}

\author{
N.P.I Arisna Putri, N. Made Pujani, N.L.P Latria Devi \\ Program Studi S1 Pendidikan IPA, Jurusan Fisika dan Pengajaran IPA \\ Universitas Pendidikan Ganesha \\ Singaraja, Indonesia
}

e-mail: \{arisna.putri, made.pujani, latria.devi\}@undiksha.ac.id,

\begin{abstract}
Abstrak
Penelitian ini bertujuan untuk menganalisis perbedaan keterampilan sosial dan prestasi belajar antara siswa yang dibelajarkan dengan model pembelajaran kooperatif tipe think pair share dan model pembelajaran langsung. Jenis penelitian ini adalah penelitian eksperimen semu dengan rancangan pretest-posttest nonequivalent control group design. Populasi dalam penelitian ini adalah seluruh siswa kelas VII SMPN 3 Banjar pada semester genap tahun ajaran 2018/2019 yang berjumlah 275 siswa. Sampel penelitian dipilih dengan menggunakan teknik cluster random sampling. Sampel yang digunakan dalam penelitian ini terdiri dari 2 kelas yang berjumlah 64 siswa sebagai kelas eksperimen dan kontrol. Data keterampilan sosial dikumpulkan menggunakan angket dengan reliabilitas 0,89 dan prestasi belajar menggunakan tes prestasi belajar dengan reliabilitas 0,69 . Data yang diperoleh dianalisis secara deskriptif dan uji manova. Hasil penelitian menunjukan bahwa (1)Terdapat perbedaan keterampilan sosial dan prestasi belajar secara bersama-sama antara siswa yang dibelajarkan dengan model pembelajaran kooperatif tipe think pair share dan model pembelajaran langsung $(\operatorname{sig}<0,05)$; (2)Terdapat perbedaan keterampilan sosial antara siswa yang belajar dengan model pembelajaran kooperatif tipe think pair share dan model pembelajaran langsung $(\mathrm{sig}<0,05)$; dan (3)Terdapat perbedaan prestasi belajar antara siswa yang belajar dengan model pembelajaran kooperatif tipe think pair share dan model pembelajaran langsung $($ sig $<0,05)$. Hasil uji LSD menunjukan bahwa model pembelajaran kooperatif tipe think pair share lebih baik daripada model pembelajaran langsung dalam meningkatkan keterampilan sosial dan prestasi belajar siswa.
\end{abstract}

Kata kunci: Keterampilan sosial, model pembelajaran kooperatif, prestasi belajar, dan think pair share.

\begin{abstract}
This research aims to analyze the differences of social skills and learning achievements between students who are taught by cooperative learning models think pair share and direct learning models. This research is a quasi-experimental research with a pretest-posttest nonequivalent control group design. The population in this study were all students of class VII of SMP 3 Banjar in the even semester of the 2018/2019 academic year totaling 275 students. The research sample was selected by cluster random sampling technique. The sample used in this research consisted of 2 classes totaling 64 students as experimental and control classes. Data on social skills were collected by questionnaires with reliability of 0,89 and learning achievement by learning achievement tests with reliability of 0.69 . The data obtained were analyzed descriptively and manova test. The results showed that (1) There were differences in social skills and learning achievement together between students who were taught with cooperative learning models think pair share type and direct learning model $(\mathrm{sig}<0.05)$; (2) There are differences in social skills between students who study with cooperative learning models think pair share and direct learning models (sig <0.05); and (3) There are differences in learning achievement between students who study with cooperative learning models think pair share and direct learning models $(\mathrm{sig}<0.05)$. The results of the LSD test show that the cooperative learning model think pair share is better than the direct learning model in improving social skills and student achievement.
\end{abstract}

Keywords: Social skills, cooperatif learning model, learning achievement, and think pair share. 


\section{PENDAHULUAN}

Kemajuan suatu bangsa ditentukan oleh kualitas generasi penerus suatu bangsa itu sendiri. Kualitas suatu generasi bangsa ditunjukan dengan pendidikan yang berkualitas tinggi untuk menciptakan sumber daya manusia yang unggul. Memasuki abad ke-21, sistem pendidikan nasional menghadapi tantangan yang sangat kompleks dalam menyiapkan kualitas sumber daya manusia yang mampu bersaing di era global. Scott (2015) menjelaskan bahwa pembelajaran abad ke21 menuntut siswa untuk memiliki kompetensi siswa (hard skills) dan keterampilan (soft skills) yang seimbang. Kompetensi dapat dilihat dari prestasi belajar siswa dan keterampilan dapat dilihat melalui keterampilan sosial karena keterampilan sosial mewakili dua dari empat elemen kunci pembelajaran abad ke-21 yaitu kolaborasi dan komunikasi. Siswa yang memiliki prestasi belajar dan keterampilan sosial yang baik akan memiliki hard skills dan soft skills yang baik sesuai dengan yang diharapkan pada pembelajaran abad ke-21. Selain itu, siswa yang memiliki hard skills dan soft skills yang baik akan menjadi sumber daya manusia yang berkualitas. Hal tersebut merupakan harapan pembangunan dan perbaikan yang tengah digencarkan oleh pemerintah Indonesia dibidang pendidikan untuk menjadikan generasi muda Indonesia menjadi generasi emas yang siap dalam menyongsong bonus demografi 2045 (Kemendikbud, 2018).

Menyikapi hal tersebut, pemerintah Indonesia telah melakukan berbagai upaya salah satunya dengan membuat Standar Nasional Pendidikan yang di dalamnya telah terdapat standar-standar yang harus dipenuhi pada lembaga kependidikan di Indonesia untuk menjadikan pembelajaran yang berkualitas. Selain itu, upaya lainnya yaitu dengan melakukan perubahan kurikulum secara berkala seperti yang telah dilakukan yaitu perubahan kurikulum tingkat satuan pendidikan (KTSP) ke kurikulum 2013 yang menekankan karakter siswa dan keaktifan siswa (student centerd) namun, pada kenyataannya tidak dapat dipungkiri masih banyak pembelajaran yang berpusat teacher centered.
Salah satu model pembelajaran yang termasuk dalam teacher centered yaitu model pembelajaran langsung. Rosdiana (2012) menyatakan bahwa model pembelajaran langsung adalah model pembelajaran yang berpusat pada guru (teacher centered) dan menekankan pada proses penyampaian materi secara verbal dari guru kepada siswa dengan maksud agar siswa dapat menguasai materi pembelajaran. Arends (2004) menyelaskan bahwa tahapan model pembelajaran langsung terdiri dari (1) menyampaikan tujuan dan mempersiapkan peserta didik, (2) menjelaskan materi dan keterampilan, (3) membimbing pelatihan, (4) mengecek pemahaman dan memberikan umpan balik, (5) memberikan kesempatan untuk latihan lanjutan. Rosdiana (2012) menjelaskan bahwa model pembelajaran langsung memiliki keterbatasan yaitu menyebabkan keterlibatan siswa kurang karena proses pembelajaran didominasi oleh guru dan hanya melibatkan komunikasi satu arah.

Alpusari dan Putra (2015) menyatakan bahwa pembelajaran merupakan proses interaksi yang melibatkan guru-siswa dan siswa- siswa. Model pembelajaran langsung menyebabkan siswa sebagai penerima informasi sehingga siswa cenderung menunggu instruksi dari guru dan menimbulkan proses pembelajaran yang membosankan. Wibawa, et al., (2018) menyatakan bahwa apabila siswa mengalami kebosanan dalam proses belajar mengajar maka sangat sulit bagi siswa untuk memahami materi pelajaran yang dibelajarkan. Pemilihan model pembelajaran yang kurang tepat akan berpengaruh terhadap prestasi belajar. Hal tersebut menyebabkan timbulnya permasalahan dalam pembelajaran yaitu prestasi belajar siswa menjadi rendah.

Menurut TIMSS (2015) kemampuan IPA siswa di Indonesia berada pada nomor urut 45 dari 48 negara yang mengikuti tes dengan skor 397. Nilai Ujian Nasional (UN) tahun ajaran 2017/2018 di provinsi Bali juga mengalami penurunan. Dinas Pendidikan provinsi Bali (2018) menyatakan bahwa hasil UN SMP/Mts provinsi Bali tahun ajaran 2017/2018 mengalami penurunan dimana pada tahun 2017 rata-rata nilai UN untuk 
mata pelajaran IPA yaitu 50,45 dan pada tahun 2018 rata-rata nilai UN siswa menjadi 50,21 . Salah satu hal yang dapat menyebabkan rendahnya prestasi belajar yaitu model pembelajaran yang diterapkan kurang tepat (Surayya, et al., 2014). Selain itu, permasalahan yang terjadi yaitu rendahnya keterampilan sosial siswa.

Scott (2015) menyatakan bahwa salah satu keterampilan yang penting dimiliki oleh siswa pada abad ke-21 adalah keterampilan sosial. Qurtubhi, et al., (2017) menyatakan bahwa keterampilan sosial perilaku seorang individu dalam melakukan interaksi sosial dan berpartisipasi dengan orang lain melalui proses belajar secara bertahap. Maryani (2011) menjelaskan bahwa keterampilan sosial terdisi atas tiga aspek yaitu (1) manajemen diri yang terdiri dari tiga indikator yaitu mengontrol emosi atau kepedulian, bergiliran atau berbagi, dan menghargai atau menghormati, (2) kemampuan akademis yang terdiri dari tiga indikator yaitu membantu atau menolong orang lain, menyampaikan pendapat, dan menerima pendapat, (3) kepatuhan yang indikatornya bersungguh-sungguh atau mengikuti petunjuk. Kholin, et al., (2016) menyatakan bahwa siswa yang memiliki keterampilan sosial baik dapat mengkonstruksi personal serta karakter siswa dalam pembelajaran yang dapat mempengaruhi kemampuan akademik dan dapat meningkatkan kreativitas siswa. Namun, banyak guru dalam mengajar tidak terlalu memperhatikan pentingnya melatih dan mengembangkan keterampilan sosial siswa. Shofatun, et al., (2016) menyatakan bahwa banyak guru dalam pembelajaran sains lebih fokus pada aspek kognitif. Jatmiko dan Wilujeng (2017) menyatakan bahwa data rata-rata hasil keterampilan sosial siswa masih rendah, aktifitas siswa dalam diskusi cenderung pasif, saling menunggu antar siswa, kurangnya minat bertanya, berpendapat dan menyampaikan hasil diskusi belum nampak jelas dalam proses pembelajaran.

Guna mengatasi hal tersebut perlu diterapkan model pembelajaran yang tepat agar keterampilan sosial dan prestasi belajar dapat diperbaiki. Widoretno, et al., (2015) menyatakan bahwa semua aspek keterampilan sosial teridentifikasi melalui diskusi, presentasi dan laporan kegiatan. Putnam (2008) menyatakan salah satu peluang menerapkan keterampilan sosial siswa yaitu dalam situasi kelompok. Susanti dan Wijayanti (2017) menyatakan bahwa model pembelajaran yang bisa digunakan untuk meningkatkan prestasi belajar dan mengembangkan sikap bekerja sama adalah model kooperatif. Model pembelajaran yang sesuai dengan uraian tersebut yaitu model pembelajaran kooperatif tipe think pair share.

Kumar dan Upadhyay (2016) menyatakan bahwa think pair share merupakan strategi yang dirancang untuk memberikan waktu kepada siswa dan struktur berpikir siswa terhadap topik tertentu yang memotivasi siswa dalam merumuskan gagasan individu dan berbagi gagasan dengan siswa yang lainnya. Adapun tahapan pembelajaran kooperatif tipe think pair share menurut Sharma dan Priyamvada (2018) yaitu (1) membentuk kelompok, (2) pemberian masalah dan topik pada siswa, (3) menganalisis permasalahan (think), (4) diskusi dengan pasangan (pair), (5) menjelaskan didepan kelas (share), (6) timbal balik. Pratiningsih, et al., (2018) menyatakan bahwa think pair share merupakan model pembelajaran yang efektif untuk membuat variasi suasana pola diskusi, memberi peserta didik lebih banyak waktu berpikir, dan merespon. Susanti dan Wijayanti (2017) memperoleh data bahwa prestasi belajar IPA siswa dan kerjasama siswa meningkat dengan menggunakan model pembelajaran think pair share. Kerjasama dapat melatih siswa untuk memiliki keterampilan baik keterampilan berpikir (thinking skill) maupun keterampilan sosial (social skill). Sehingga dengan diberikannya model pembelajaran kooperatif tipe think pair share dapat mengatasi masalah tentang keterampilan sosial siswa dan prestasi belajar IPA siswa.

Berdasarkan uraian tersebut dipandang perlu dilaksakannya penelitian lebih lanjut untuk memperoleh data dan mengetahui pengaruh model pembelajaran kooperatif terhadap keterampilan sosial dan prestasi belajar. Adapun tujuan penelitian ini yaitu (1) menganalisis perbedaan 
keterampilan sosial dan prestasi belajar siswa antara siswa yang dibelajarkan dengan model pembelajaran kooperatif tipe think pair share dan siswa yang dibelajarkan dengan model pembelajaran langsung, (2) menganalisis perbedaan keterampilan sosial siswa antara siswa yang dibelajarkan dengan model pembelajaran kooperatif tipe think pair share dan siswa yang dibelajarkan dengan model pembelajaran langsung, (3) menganalisis perbedaan prestasi belajar siswa antara siswa yang dibelajarkan dengan model pembelajaran kooperatif tipe think pair share dan siswa yang dibelajarkan dengan model pembelajaran langsung.

\section{METODE}

Jenis penelitian yang digunakan dalam penelitian ini adalah jenis penelitian quasi eksperimen. Adapun desain penelitian yang dilaksanakan saat penelitian yaitu PretestPosttest Non-equivalent Control Group Design. Adapun populasi dari penelitian ini yaitu seluruh siswa kelas VII SMP N 3 Banjar yang terbagi dalam beberapa kelas yaitu VII.1-VII.8. Sampel penelitian yaitu siswa kelas VII.2 sebanyak 32 siswa (kelas eksperimen) dan siswa kelas VII.4 sebanyak 32 siswa (kelas kontrol), dengan teknik sampling yang digunakan yaitu cluster random sampling.

Variabel dalam penelitian ini, terdapat dua variabel yaitu variabel bebas dan variabel terikat. Variabel bebas pada penelitian ini yaitu model pembelajaran kooperatif tipe think pair share dan model pembelajaran langsung yang digunakan oleh sekolah tersebut sebelumnya. Variabel terikat yaitu keterampilan sosial dan prestasi belajar. Teknik pengumpulan data yang digunakan yaitu tes tulis pilihan ganda dengan jumlah butir soal sebanyak 30 butir untuk mengumpulkan data prestasi belajar dan angket jenis skala Linkert dengan jumlah soal 30 butir untuk mengumpulkan data keterampilan sosial siswa.

Teknik analisis data yang digunakan yaitu analisis deskriptif dan uji Manova (Multivariat Analysis of Variance) serta uji lanjut yaitu LSD. Sebelum dilakukannya uji manova, harus dilakukan uji prasyarat yaitu uji normalitas, uji homogenitas, uji homogenitas matriks varian, dan uji kolinieritas. Setelah diperoleh hasil dari uji manova, dilanjutkan dengan uji lanjut manova yaitu uji LSD (Least Significant Diference). Semua pengujian hipotesis dilakukan pada taraf signifikansi 5\% $(\alpha=0,05)$ dan dianalisis dengan bantuan program SPSS 22 for windows.

\section{HASIL DAN PEMBAHASAN}

Hasil penelitian memaparkan mengenai distribusi frekuensi, skor rata-rata (mean), standar deviasi (SD), <g> keterampilan sosial dan prestasi belajar siswa yang diperoleh dari skor pretest dan posttest menggunakan angket untuk keterampilan sosial dan menggunakan tes pilihan ganda untuk prestasi belajar. Model pembelajaran kooperatif tipe think pair share disingkat menjadi MTPS dan model pembelajaran langsung disingkat menjadi MPL. Hasi dari pretest dan posttest keterampilan sosial diuraikan pada Tabel 1.

Tabel 1. Profil Keterampilan Sosial Siswa

\begin{tabular}{clllll}
\hline Statistik & \multicolumn{2}{c}{ Think Pair Share } & \multicolumn{2}{c}{ Direct Instruction } \\
& Pre & Post & Pre & Post \\
\hline Mean & 59,96 & 83,13 & 58,92 & 71,58 \\
SD & 7,88 & 5,12 & 5,64 & 4,82 \\
$<\mathrm{g}>$ & & 0,58 & & \multicolumn{2}{c}{0,31} \\
\hline
\end{tabular}

Berdasarkan Tabel 1, apabila dilihat dari nilai $\langle g\rangle$, kelompok MTPS memiliki nilai yang lebih tinggi dibandingkan dengan kelompok MPL baik pada nilai rata-rata (mean), simpangan baku (SD), nilai maksimum, maupun nilai minimum. Pada nilai rata-rata pretest diperoleh pada kelompok MTPS lebih besar daripada 
kelompok MPL dengan selisih sebesar 1,04. Pada nilai pretest dan posttest kedua kelompok yaitu kelompok MTPS dan MPL memang apabila dicermati kedua kelompok mengalami perubahan nilai dari nilai pretest yang rendah menjadi lebih meningkat pada nilai posttest, namun perubahan nilai dari pretest ke posttest lebih besar terjadi pada kelompok MTPS. Hasil ini menunjukan bahwa MTPS memberikan pengaruh yang lebih baik daripada MPL apabila dilihat dari nilai $<g>$ pada nilai rata-rata pretest dan posttest yang diperoleh dari MTPS maupun MPL.

Berdasarkan hasil distribusi frekuensi kualifikasi nilai $\langle g>$ keterampilan sosial tersebut, untuk mempermudah mengamati perbedaan nilai $<g>$ keterampilan sosial antara kelompok MTPS dengan kelompok MPL, dapat dilihat pada diagram batang. Gambaran mengenai distribusi frekuensi keterampilan sosial data $<g>$ pada kelompok MTPS dan kelompok MPL dapat diamati pada Gambar 1 berikut.

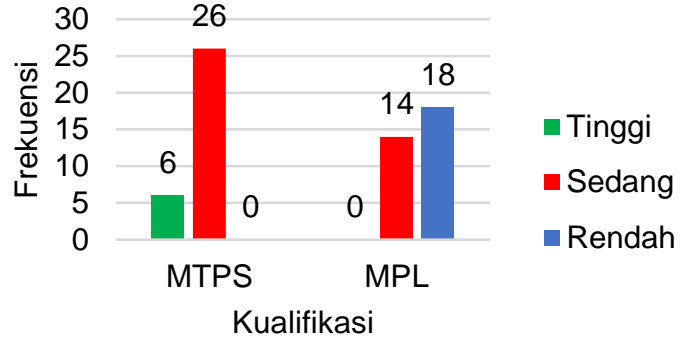

Gambar 1. Diagram Batang Distribusi

Frekuensi $<g>$ Keterampilan Sosial

Gambar 1 menunjukan bahwa paada kelompok MPTS nilai $<g>$ diperoleh enam siswa berada pada kategori tinggi dan tidak ada satupun siswa pada kategori rendah, sedangkan hasil tersebut berbanding terbalik dengan kelompok MPL yang memperoleh siswa lebih banyak pada kategori rendah dan tidak satupun siswa terkategori tinggi. Pencapaian nilai tiap-tiap indikator keterampilan sosial dianalisis dengan menggunakan nilai $<g>$ seperti pada Tabel 2.

Tabel 2. Profil Ketercapaian Indikator Keterampilan Sosial

\begin{tabular}{lcc}
\hline \multicolumn{1}{c}{ Indikator Keterampilan Sosial } & Think Pair Share & Direct Instruction \\
\hline Mengontrol emosi/kepedulian & 0,61 & 0,32 \\
Bergiliran/berbagi & 0,60 & 0,34 \\
Menghargai/menghormati & 0,60 & 0,28 \\
Membantu/menolong orang lain & 0,48 & 0,22 \\
Menyampaikan pendapat & 0,51 & 0,26 \\
Menerima pendapat & 0,43 & 0,29 \\
Bersungguh-sungguh/mengikuti petunjuk & 0,59 & 0,32 \\
\hline
\end{tabular}

Tabel 2 menunjukan bahwa kelompok MTPS memiliki $<g>$ yang lebih tinggi dibandingkan kelompok MPL. Hal ini disebabkan pada model pembelajaran kooperatif tipe think pair share siswa diberikan waktu untuk melakukan diskusi dan sharing dengan siswa yang lain untuk menemukan jawaban dari topik yang diberikan sehingga siswa menjadi terlatih dalam mengembangkan keterampilan sosialnya, sedangkan pada model pembelajaran langsung guru masih mendominasi proses pembelajaran dan hanya terjadi proses interaksi satu arah yaitu dari guru-siswa. Hal tersebut menjadikan siswa cenderung menunggu guru untuk memberikan instruksi sehingga siswa tidak dapat melatih dan mengembangkan keterampilan sosial siswa. Data selanjutnya mendeskripsikan data prestasi belajar siswa yang dibelajarkan menggunakan model pembelajaran kooperatif think pair share dan model pembelajaran langsung.

Pada deskripsi umum prestasi belajar dipaparkan mengenai data pretest, posttest, $<g>$, deskripsi frekuensi dan presentase nilai kualifikasi serta deskripsi pencapaian tiaptiap indikator prestasi belajar pada kelompok MTPS dan kelompok MPL pada materi pencemaran lingkungan. Hasil pretest prestasi belajar menyatakan kemampuan awal yang dimiliki oleh siswa sebelum 
diberikan perlakuan dan hasil posttest prestasi belajar menunjukan kemampuan akhir yang dimiliki oleh siswa setelah diberikannya perlakuan dengan pemberian model pembelajaran. Hasil dari pretest dan posttest kemudian dianalisis dengan menggunakan nilai $<g>$. Deskripsi statistik skor pretest, posttest dan $<g>$ ditampilkan pada Tabel 3 berikut.

Tabel 3. Profil Prestasi Belajar Siswa

\begin{tabular}{crrrrr}
\hline Statistik & \multicolumn{2}{c}{ Think Pair Share } & \multicolumn{2}{c}{ Direct Instruction } \\
& Pre & Post & Pre & Post \\
\hline Mean & 51,52 & 79,79 & 50,16 & 68,13 \\
SD & 10,51 & 7,28 & 9,31 & 5,35 \\
<g & & 0,58 & & \multicolumn{2}{c}{0,36} \\
\hline
\end{tabular}

Berdasarkan Tabel 3 menunjukan bahwa kelompok MTPS memperoleh nilai $<g>$ untuk rata-rata (mean) lebih tinggi dibandingkan dengan nilai $<g>$ untuk ratarata (mean) pada kelompok MPL. Simpangan baku (SD) pada kelompok MTPS memperoleh nilai $<g>$ yang lebih kecil dari pada kelompok MPL dengan selisih nilai $<g>$ antara kelompok MTPS dengan kelompok MPL sebesar 0,01. Nilai maksimum pada kelompok MTPS memperoleh nilai $<g>$ dua kali lebih besar dibandingkan dengan kelompok MTPS. Perolehan nilai minimum antara kelompok MTPS dengan kelompok MPL memperoleh nilai $\langle g>$ yang sama. Walaupun nilai $<g>$ kelompok MTPS memiliki satu nilai yang lebih kecil dari kelompok MPL, namun secara keseluruhan nilai $<g>$ pada kelompok MTPS lebih besar dibandingkan dengan kelompok MPL.

Guna mempermudah dalam mengamati perbedaan frekuensi nilai $\langle g>$ prestasi belajar siswa antara kelompok
MTPS dan kelompok MPL disajikan dalam gambar diagram batang pada Gambar 2 .

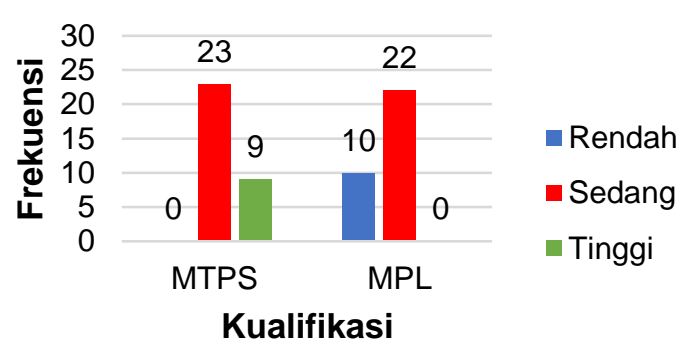

Gambar 2. Diagram Batang Nilai $<g>$ Prestasi belajar

Gambar 2 menunjukan kelompok MTPS memperoleh nilai $<g>$ yang lebih tinggi daripada kelompok MPL. Hal tersebut dikarenakan kelompok MTPS memperoleh nilai $<g>$ yang terkategori tinggi sebanyak sembilan orang siswa, sedangkan pada kelompok MPL tidak terdapat satupun siswa yang memperoleh kategori tinggi. Pencapaian tiap-tiap indikator prestasi belajar disajikan pada Tabel 4 .

Tabel 4. Profil Ketercapaian Indikator Prestasi Belajar

\begin{tabular}{lcc}
\hline \multicolumn{1}{c}{ Indikator Keterampilan Sosial } & Think Pair Share & Direct Instruction \\
\hline Memahami (C2) & 0,63 & 0,30 \\
Mengaplikasikan (C3) & 0,64 & 0,37 \\
Menganalisis (C4) & 0,56 & 0,29 \\
Mengevaluasi (C5) & 0,54 & 0,32 \\
\hline
\end{tabular}


Tabel 4 menunjukan bahwa model pembelajaran kooperatif tipe think pair share (MTPS) memperoleh nilai $<g>$ lebih besar daripada model pembelajaran langsung (MPL). Siswa yang diajarkan dengan model pembelajaran kooperatif memperoleh nilai $\langle g\rangle$ yang termasuk dalam kategori sedang, sedangkan pada model pembelajaran langsung terdapat satu indikator prestasi belajar yang termasuk dalam kategori rendah yaitu indikator menganalisis. Secara keseluruhan, model pembelajaran kooperatif tipe think pair share lebih baik dalam mempengaruhi keterampilan sosial dan prestasi belajar dibandingkan dengan model pembelajaran langsung, selanjutnya untuk mengetahui apakah peningkatan itu signifikan atau tidak dilakukan uji asumsi dan uji hipotesis.

Hasil uji asumsi baik uji normalitas, uji homogenitas dan uji homogenitas matriks varian menunjukan angka signifikan (sig $>0,05)$ serta uji kolinieritas memperoleh nilai $\left(r_{y 1 y 2}<0,800\right)$ sehingga hal tersebut menyatakan bahwa data yang diperoleh telah lolos uji prasyarat dan dilanjutkan ke uji hipotesis yaitu dengan uji Manova.

Hasil uji Manova untuk pengujian hipotesis yang pertama memperoleh hasil $($ sig $<0,05)$ yang menyebabkan $\mathrm{H}_{0}$ ditolak dan $\mathrm{H}_{1}$ diterima, sehingga terdapat perbedaan keterampilan sosial dan prestasi belajar secara bersama-sama antara siswa yang dibelajarkan dengan model kooperatif tipe think pair share dan siswa yang dibelajarkan dengan model pembelajaran langsung. Hasil pengujian hipotesis kedua diperoleh angka signifikan (sig $>0,05$ ) yang menyebabkan $\mathrm{H}_{0}$ ditolak dan $\mathrm{H}_{1}$ diterima, sehingga terdapat perbedaan keterampilan sosial antara siswa yang dibelajarkan menggunakan model pembelajaran kooperatif tipe think pair share dengan model pembelajaran langsung. Hasil uji hipotesis ketiga diperoleh angka signifikan (sig $>0,05)$, sehingga terdapat perbedaan prestasi belajar antara siswa yang dibelajarkan menggunakan model pembelajaran kooperatif tipe think pair share dengan model pembelajaran langsung. Setelah dilakukannya uji hipotesis dilanjutkan dengan uji lanjut yaitu LSD. Hasil uji LSD untuk hipotesis kedua diperoleh $\left|\mu_{i}-\mu_{j}\right|>$ $L S D(0,268>0,06)$ sehingga $\mathrm{H}_{1}$ diterima yaitu terdapat perbedaan nilai rata-rata keterampilan sosial antara kelompok MTPS dan kelompok MPL. Hasil uji LSD untuk hipotesis ketiga diperoleh $\left|\mu_{i}-\mu_{j}\right|>$ $\operatorname{LSD}(0,228>0,08)$ sehingga $\mathrm{H}_{1}$ diterima yaitu terdapat perbedaan nilai rata-rata prestasi belajar antara kelompok MTPS dan kelompok MPL. Secara keseluruhan uji lanjut (LSD) menyatakan bahwa model pembelajaran kooperatif tipe think pair share lebih baik dalam mempengaruhi keterampilan sosial dan prestasi belajar dibandingkan model pembelajaran langsung.

Berdasarkan hasil analisis statistik deskriptif dan uji hipotesis tersebut, maka model pembelajaran kooperatif tipe think pair share lebih baik dalam mempengaruhi keterampilan sosial dan prestasi belajar dibandingkan model pembelajaran langsung. Hal ini disebabkan karena model pembelajaran kooperatif tipe think pair share adalah model pembelajaran yang dirancang agar siswa dapat mengembangkan kemampuan berpikir dalam memahami materi yang diberikan oleh guru baik secara individual maupun secara berkelompok sehingga gagasan ataupun pemahaman yang dimiliki oleh setiap siswa terhadap suatu materi ataupun dalam memecahkan masalah akan saling didiskusikan untuk memperoleh jawaban yang tepat. Proses ini dapat melatih siswa dalam berkomunikasi, berkoordinasi, saling menghargai, dan dapat saling menambah serta melengkapi pemahaman setiap siswa. Selain itu, tahapan model pembelajaran kooperatif tipe think pair share juga mempengaruhi keterampilan sosial dan prestasi belajar siswa. Apapun tahapan-tahapan tersebut akan dijelaskan sebagai berikut: tahap pertama yaitu pembagian kelompok, pembagian kelompok dilakukan oleh guru dimana sistem pembagian kelompok diatur jumlah siswa laki-laki dan perempuan dalam satu kelompok agar kelompok tidak homogen.

Tahap kedua yaitu menyajikan topik atau permasalahan kepada siswa, topik atau permsalahan diberikan melalui lembar kerja siswa (LKS) yang telah ditentukan 
oleh guru. Topik atau permasalahan yang telah diberikan kepada masing-masing siswa akan dianalisis terlebih dahulu secara individu oleh tiap-tiap siswa. Proses tersebut dinamakan proses think, yang mana proses tersebut sudah masuk pada tahapan ketiga pembelajaran.

Tahap ketiga yaitu think atau berpikir, pada tahap ini siswa secara individu mulai menggali dan mengumpulkan gagasangagasan yang telah diketahui sebelumnya maupun gagasan yang baru diketahunya untuk mendapatkan jawaban dari setiap permasalahan yang diberikan dalam lembar kerja siswa (LKS). Aktivitas ini akan melatih kemampuan berpikir siswa dalam mengumpulkan sumber-sumber dan pengetahuan yang relevan dalam memecahkan masalah yang diberikan. Kemampuan berpikir yang terus dirangsang dan dikembangkan akan menjadikan siswa lebih kritis dan kreatif dalam mencari suatu pemecahan masalah yang benar dan tepat. Pada tahap ini siswa akan menggunakan kemampuan dalam memahami (C2), menganalisis (C4) dan mengevaluasi (C5) untuk menjawab pertanyaan dan permasalahan yang diberikan, sehingga indikator prestasi belajar siswa berperan banyak pada tahap think.

Tahap keempat yaitu pair, tahap ini merupakan tahap dimana siswa yang awalnya secara individu telah mencari dan mengumpulkan sumber-sumber untuk menjawab permasalahan yang diberikan, kemudian bertemu dengan pasangan atau kelompok untuk mendiskusikan dan saling bertukar pendapat mengenai gagasan masing-masing. Pada tahap ini siswa akan memperoleh tambahan pengetahuan dari hasil diskusi untuk melengkapi ataupun memperbaiki jawaban yang telah dibuat oleh siswa sebelumnya pada tahap think menjadi gagasan bersama yang telah mengalami penyempurnaan dari berbagai gagasan/ide yang telah dikumpulkan sebelumnya. Proses ini merupakan proses yang sangat penting karena pada proses ini siswa mulai mengaplikasikan (C3), menganalisis (C4) dan mengevaluasi (C5) setiap gagasan yang disampaikan masingmasing individu dalam satu kelompok untuk memperoleh jawaban yang tepat. Selain itu, pada tahap ini juga mendorong keterampilan sosial siswa seperti mengontrol emosi/ kepedulian, menyampaikan pendapat, menerima pendapat, saling menghargai dan menghormati pendapat satu sama lain.

Tahap kelima yaitu share, pada tahap ini hasil diskusi yang telah diskusikan bersama-sama pada tahap pair kemudian akan disampaikan kepada siswa yang lain oleh kelompok penyaji didepan kelas. Setelah kelompok penyaji selesai menjelaskan hasil diskusinya maka akan diadakan sesi tanya jawab apabila terdapat siswa yang masih belum mengerti atau terdapat kelompok atau siswa lain yang mempunyai tanggapan berbeda ataupun terdapat siswa yang memberikan sanggahan pendapat terhadap kelompok penyaji. Proses ini juga merupakan proses yang sangat penting karena pada proses ini siswa dilatih dalam berkomunikasi atau menyampaikan pendapat yang baik didepan umum, menerima pendapat orang lain apabila memang hasil diskusi yang diberikan kurang tepat, saling menghargai dan menghormati, mengontrol emosi dan kepedulian, bersungguh-sungguh dan mengikuti petunjuk. Tidak hanya terpaku pada kemampuan akademik namun bagaimana pengetahuan akademik yang siswa miliki dapat dibagikan kepada orang banyak ataupun masyarakat lainnya, sehingga peran keterampilan sosial sangatlah penting dimiliki oleh siswa.

Tahapan yang terakhir yaitu timbal balik oleh guru, setelah siswa selesai melakukan aktivitasnya dari tahapan think sampai share kemudian proses pembelajaran akan diambil alih oleh guru untuk memberikan timbal balik dari setiap pernyataan yang diberikan siswa supaya tidak terjadi misskonsepsi. Selama pembelajaran inti berlangsung guru hanya bersifat sebagai fasilitator dan mediator namun pada tahap ini guru memiliki peranan penting untuk memberikan timbal balik dari hasil diskusi yang telah dilakukan oleh siswa baik untuk menjelaskan pernyataan siswa yang salah atau kurang tepat maupun melengkapi pernyataan yang telah diberikan oleh siswa. Tahapantahapan ini akan melatih siswa dalam mengembangkan indikator-indikator prestasi belajar yaitu memahami, mengaplikasikan, menganalisis dan 
mengevaluasi serta indikator keterampilan sosial yaitu mengontrol emosi dan kepedulian, bergiliran atau berbagi, menghargai atau menghormati, membantu atau menolong orang lain, menyampaikan pendapat, menerima pendapat dan bersungguh-sunggu dan mengikuti petunjuk. Siswa yang terbiasa belajar menggunakan model pembelajaran ini maka siswa akan terbiasa untuk berpikir dan terbiasa belajar untuk menemukan pengetahuannya sendiri, sehingga semakin banyak siswa mempelajari bahan pengajaran maka semakin banyak pengalaman yang diperoleh dan diingat yang akan berdampak dengan prestasi belajar siswa.

Berbeda dengan pembelajaran langsung dimana guru lebih mendominasi dan berperan dalam mendefinisikan, menjelaskan, mendemonstrasikan, menyimpulkan dan menerapkan prinsip atau konsep dalam proses pembelajaran, sehingga siswa menjadi pasif. Model pembelajaran langsung membuat siswa hanya terpaku pada guru saja tanpa harus mengalami sendiri proses perolehan ilmu atau materi. Hal ini sejalan dengan penelitian yang dilakukan oleh Adnyani, et al., (2019) menyatakan bahwa model pembelajaran langsung dapat mengakibatkan siswa menjadi pasif, siswa yang pasif akan mengakibatkan siswa kesulitan dalam memecahkan permasalahan dalam pelajaran IPA, sehingga hal tersebut dapat menghambat kemampuan berpikir siswa yang berdampak pada prestasi belajar siswa. Selain itu, Putra, et al., (2019) yang menyatakan bahwa siswa yang terbiasa menerima pengetahuan atau informasi yang diberikan oleh guru tanpa mau berusaha dan mengembangkan potensi yang dimiliki akan berdampak pada kurangnya motivasi dan minat belajar siswa. Namun tidak dipungkiri bahwa model pembelajaran langsung juga memiliki kelebihan seperti guru bisa mengontrol urutan dan keluasan materi pembelajaran yang disampaikan, dan model pembelajaran langsung diangkat efektif apabila materi yang harus dikuasai cukup luas sedangkan waktunya sangat terbatas. Kelebihan dari model pembelajaran langsung tidak cukup untuk membuat siswa aktif dan dapat mengembangkan keterampilan sosialnya. Selain itu, model pembelajaran langsung kurang memberikan tantangan kepada siswa sehingga menimbulkan rasa jenuh yang menyebabkan penurunan minat belajar yang berdampak pada prestasi belajar siswa menjadi rendah.

Hasil penelitian ini relevan dengan hasil penelitian yang dilakukan oleh Sharma dan Priyamvada (2018) yang menyatakan bahwa model pembelajaran kooperatif tipe think pair share efektif dalam meningkatkan berpikir kritis, prestasi belajar, interaksi dan partisipasi siswa didalam kelas serta melatih kemampuan berkomunikasi siswa yang dapat berdampak pada keterampilan sosial siswa yang mana kemampuankemampuan tersebut sangatlah penting dalam membantu siswa dimasa depan dan membantu kehidupan siswa dimasa depan diluar sekolah. Jatmiko dan Wilujeng (2017) juga menjelaskan pada penelitiannya bahwa secara umum model pembelajaran kooperatif dapat mempengaruhi keterampilan sosial siswa. Penelitian juga sejalan dengan penelitian yang dilakukan oleh Kumar dan Upadhyay (2016) menyatakan model think pair share lebih baik daripada model konvensional dan model pembelajaran think pair share dapat meningkatkan pemahaman siswa, kemampuan menghubungkan dan menganalisis materi baru. Selain itu, penelitian ini juga sejalan dengan penelitian yang dilakukan oleh Nurjannah (2019) yang menyatakan bahwa model pembelajaran think pair share dapat mempengaruhi keaktifan dan hasil belajar IPA, dimana pada penelitian ini siswa menjadi lebih aktif dalam mengemukakan pendapat maupun bekerjasama.

Secara keseluruhan pembahasan maka jelas bahwa MTPS mampu mempengaruhi prestasi belajar siswa dibandingkan dengan siswa yang dibelajarkan menggunakan MPL. Adapun temuan yang ditemukan oleh peneliti yaitu (1) Indikator membantu atau menolong orang lain dan indikator menerima pendapat pada keterampilan sosial diperoleh nilai $<\mathrm{g}>$ paling rendah diantara seluruh indikator keterampilan sosial. Hal tersebut disebabkan karena pada saat 
proses pembelajaran terdapat penghargaan yang diberikan oleh guru kepada kelompok yang aktifitas dan hasil diskusinya memperoleh hasil yang baik dan benar, sehingga siswa dalam kelompoknya termotivasi untuk memperoleh penghargaan tersebut. Hidayat (2018) menyatakan bahwa pemberian penghargaan kepada siswa dapat memotivasi siswa dalam pembelajaran, namun pemberian penghargaan juga dapat menimbulkan rasa kompetitif siswa sehingga siswa akan bersaing atau melakukan kompetisi dengan siswa-siswa yang lain dalam proses pembelajaran berlangsung. Rasa kompetitif dalam tiap kelompok tersebut menyebabkan tiap-tiap kelompok fokus pada pencapaian kelompok mereka masing-masing. Oleh sebab itu, pemberian penghargaan perlu diperhatikan dengan melihat keaktifan siswa dalam pembelajaran.

(2) Kemampuan menganalisis (C4) dan kemamuan mengevaluasi (C5). Hal tersebut disebabkan karena siswa mamu mengaitkan dan menghubungkan pengetahuan atau konsep yang dimilikinya dengan keadaan nyata pada kehidupan sehari-hari, siswa cenderung hanya menjawab dan memecahkan masalah LKS dengan menyalin konsep yang terdapat pada buku. Selain itu, Anderson dan Krathwohl (2001) menyatakan bahwa ranah kognitif jenjang C4 (menganalisis), C5 (mengevaluasi), dan C6 (mencipta) termasuk dalam kemampuan tingkat tinggi atau high order thinking sehingga tingkat kesukarannya pun lebih sukar diabndingkan jenjang C1, C2, maupun C3. Oleh sebab itu, siswa perlu dilatih kemampuan menganalisis dan mengevaluasi dengan memberikan latihan soal dan LKS yang menuntut kemampuan menganalisis dan mengevaluasi secara bertahap.

(3) MTPS dapat mempengaruhi keterampilan sosial dan prestasi belajar siswa dengan hasil keterampilan sosial dan prestasi belajar yang diperoleh kelompok siswa yang dibelajarkan menggunakan MTPS memiliki kategori sedang secara pencapaian rata-rata maupun pencapaian tiap-tiap indikatornya. Hasil tersebut seharusnya dapat ditingkatkan untuk mencapai kategori tinggi, namun karena terdapat beberapa hambatan sehingga nilai yang dihasilkan hanya mencapai pada kategori sedang. Beberapa hambatan yang peneliti temui saat penelitian yaitu keterbatasan pengetahuan siswa mengenai MTPS sehingga pada awal pertemuan siswa terlihat susah untuk menyesuaikan dengan model yang sedang diterapkan yaitu MTPS, pada tahap share atau penyampaian hasil didepan kelas banyak ditemui siswa yang malu-malu, adanya keterbatasan sarana pembelajaran seperti alat dan bahan praktikum serta bahan ajar yang disediakan sekolah untuk siswa, serta siswa juga belum terbiasa dalam mengerjakan LKS MTPS.

Hambatan-hambatan tersebut, peneliti dapat mengatasi dengan cara berikut yaitu memberikan penjelasan informasi terkait tahapan-tahapan dan aturan dalam model yang harus siswa lakukan pada saat pembelajaran berlangsung sehingga siswa mengetahui alur pembelajaran dan dapat membiasakan diri dengan MTPS sehingga pembelajaran dalam berlangsung secara efektif, dan siswa juga tidak mengalami kesulitan selama pembelajaran. Selain itu, guru dapat menginstruksikan kepada siswa untuk mempelajari materi sebelumnya dirumah melalui sumber manapun. Guru dapat menginstruksikan siswa untuk membaca dan memberikan arahan atau penjelasan singkat mengenai cara mengerjakan LKS MTPS.

\section{SIMPULAN DAN SARAN}

Berdasarkan hasil penelitian dan pembahasan adapun simpulan dari penelitian ini yaitu (1) terdapat perbedaan keterampilan sosial dan prestasi belajar secara bersama-sama antara siswa yang dibelajarkan menggunakan model pembelajaran kooperatif tipe think pair share dengan siswa yang dibelajarkan menggunakan model pembelajaran langsung, (2) terdapat perbedaan keterampilan sosial antara siswa yang dibelajarkan menggunakan model pembelajaran kooperatif tipe think pair share dengan siswa yang dibelajarkan menggunakan model pembelajaran 
langsung, (3) terdapat perbedaan prestasi belajar antara siswa yang dibelajarkan menggunakan model pembelajaran kooperatif tipe think pair share dengan siswa yang dibelajarkan menggunakan model pembelajaran langsung. Hasil analisis uji lanjut juga menunjukan bahwa model pembelajaran kooperatif tipe think pair share lebih baik dalam mempengaruhi keterampilan sosial dibandingkan dengan model pembelajaran langsung.

Berdasarkan hasil penelitian dan pembahasan maka dapat diajukan beberapa saran sebagai berikut. (1) Bagi Guru (khususnya guru IPA) disarankan untuk menerapkan model pembelajaran kooperatif tipe think pair share dalam pembelajaran di kelas karena model pembelajaran ini mampu melatihkan dan mengembnagkan keterampilan sosial siswa, partisipasi dan prestasi siswa dalam pembelajaran, agar penerapan model pembelajaran ini dapat berpengaruh dengan optimal, maka guru harus menginfokan aturan dan langkah pembelajaran, serta memperhatikan materi dan karakter siswa. (2) Kepada peneliti lainnya agar melakukan penelitian lebih lanjut terhadap bagian-bagian sains yang lain untuk menguji efektivitas model pembelajaran kooperatif tipe think pair share pada aspek lainnya. (3) Penelitian selanjutnya yang menggunakan keterampilan sosial sebagai variabel terikat supaya dalam pengambilan data tidak hanya menggunakan kuesioner teknik angket saja, namun dapat ditambahkan dengan menggunakan lembar observasi atau pengamatan untuk memperoleh data yang valid dan tepat.

\section{DAFTAR PUSTAKA}

Adnyani, I.G.A.A.W., Pujani, N.M., \& Juniartina, I.P.P. 2019. Pengaruh Model Learning Cycle Model 7E Terhadap Keterampilan Berpikir Kritis Siswa. Jurnal Pendidikan dan Pembelajaran Sains Indonesia. Volume 1 (1) hal 1-12.

Alpusari, M., \& Putra, R A. 2015. The Application of Cooperatif Learning Think Pair Share (TPS) Model to Increase the Process Science Skills in Class IV Elementary School
Number 81 Pekanbaru City. International Journal of Science and Research. Volume 4 (4) hal 28052808.

Anderson, L.W., \& Krathwohl, D.R. 2001. Kerangka Landasan untuk Pembelajaran, Pengajaran, dan Assesment: Revisi Taksonomi Pendidikan Bloom. Terjemahan Agung Prihantoro. Yogyakarta: Pustaka Pelajar.

Arends, I Ricard. 2004. Strategi-Strategi Belajar Edisi 2. Surabaya: UNESAUniversity Press. Diterjemahkan oleh Prof. Dr. Mohamad Nur.

Hidayat, M.Y. 2018. Hubungan Kebutuhan Penghargaan (Esteem Needs) dan Kompetisi dalam Belajar (Learning of Competition) dengan Kreativitas Belajar Fisika Siswa MTs Madani Alauddin Pao-Pao Kabupaten Gowa. Jurnal Inspiratif Pendidikan. Volume 7 (1) hal 66-75.

Jatmiko, A \& Wilujeng, I. 2017. Analisis Keterampilan Sosial Siswa Pada Metode Kooperatif Dalam Pembelajaran IPA. Jurnal Kependidikan. Volume 1 (2) hal 240252.

Kementrian Pendidikan dan Kebudayaan. 2018. Peta Jalan Generasi Emas Indonesia 2045.

Kholin, M., Meurs, J A., Gerhard Blickle, Wihler, A., Ewen, C., \& Momm, T D. 2016. Refining The OpennessPerfomance Relationship: Construct Specificity, Contextualization, Social Skill, and the Combination of Trait Self and Other Ratings. Journal of Personality Assement, Volume 98 (3) hal 277-288.

Kumar, R \& Upadhyay, K A. 2016. Effectiveness Of Think -Pair-Share Technique Over Conventional Technique In Promoting Science Education At Upper Primary Standard. Jurnal International Education and Research Journal. Volume 2 (11) hal 89-90.

Martin, M.O., Mulis, I.V.S., Foy, P., \& Hooper, M. 2015. TIMSS 2015 International Research in Science. IEA: TIMSSdanPIRLS. Lynch School of Education, Boston College. 
Maryani, E. 2011. Pengembangan Program Pembelajaran IPS untuk Peningkatan Keterampilan Sosial. Alfabeta: Bandung.

Nurjannah, P F. 2019. Pengaruh Model Pembelajaran Think Pair Share Terhadap Keaktifan dan Hasil Belajar IPA. Indonesian Journal of Educational Research and Review, Volume 2 (1) hal 76-81. Pemerintah Provinsi Bali Dinas Pendidikan. 2018. Hasil Ujian Nasional Utama dan Susulan SMP/MTs Provinsi Bali Tahun Pelajaran 2017/2018. Denpasar: Dinas Pendidikan.

Pemerintah Provinsi Bali Dinas Pendidikan. 2018. Hasil Ujian Nasional Utama dan Susulan SMP/MTs Provinsi Bali Tahun Pelajaran 2017/2018. Denpasar: Dinas Pendidikan.

Pratiningsih, J A., Sahidu, H., \& Kosim. 2018. Pengaruh Model Pembelajaran Kooperatif Tipe Think Pair Share dengan Metode Eksperimen Terhadap Hasil Belajar Peserta Didik MAN Lombok Barat. Jurnal Pendidikan Fisika dan Teknologi, Volume 4 (1) hal 90-97.

Putnam, J Wachholz. 2008. Cooperative Learning and Strategies for Inclusion: Celebrating Diversity in The Classroom (Second Edition). Baltimore, Maryland: Paul $\mathrm{H}$ Brookes Publishing Co.

Putra, I.B.P.A., Pujani, N.M., \& Juniartina, P.P. 2019. Pengaruh Model Pembelajaran Kooperatif Tipe Jigsaw Terhadap Pemahaman Konsep Siswa. Jurnal Pendidikan dan Pembelajaran Sains Indonesia. Volume 1 (1) hal 25-35.

Qurtubhi, W M., Abdulkarim, A., \& Iqbal, M. Effect of Cooperative Learning Model Type Think Pair and Share (TPS) on Student Cooperation. International Journal of Pedagogy and Social Studies, Volume 2 (2) hal 35-58.

Rosdiana, D. 2012. Model Pembelajaran Langsung dalam Pendidikan Jasmani dan Kesehatan. Bandung: Alfabeta.

Scott, C L. 2015. The Future of Learning 2: What Kind Of Learning For The 21st
Century?. Education Research and Foresight Working Papers, UNESCO.

Sharma, H L \& Priyamvada. 2018. TPS (Think Pair Share): An Effective Cooperative Learning Strategy for Unleashing Discussion in Classroom Interaction. International Journal of Research in Social Sciences. Volume 8 (5) hal 91-100.

Shofatun, A., Ibrahim, M., \& Wasis. 2016. Pembelajaran IPA Terpadu Melalui Project Based Learning Dalam Melatihkan Academic dan Social Skill Siswa SMP. Jurnal Pendidikan Sains Pascasarjana Universitas Negeri Surabaya. Volume 6 (1) hal 1150-1158.

Surayya, L., Subagia, I.W., \& Tika I.N. $2014 . \quad$ Pengaruh Model Pembelajaran Think pair share Terhadap Hasil Belajar Ipa Ditinjau Dari Keterampilan Berpikir Kritis Siswa. e-Journal Program Pascasarjana Universitas Pendidikan Ganesha. Volume 4 (1) hal 1-11.

Susanti, A \& Astuti, W. 2017. Think Pair Share: Hasil Belajar IPA dan Kerjasama Siswa. Jurnal Pijar MIPA. Volume 7 (2) hal 51-59.

Wibawa, I M C., Rati, N W., \& Santra, P. 2018. Pengaruh Model Pembelajaran Think Pair Share Berbantuan Power Point Terhadap Hasil Belajar IPA. Jurnal IImiah Pendidikan dan Pembelajaran. Volume 2 (1) hal 38-46.

Widoretno, S., Susilo, H., Abdurrajak, Y., \& Amin, M. 2015. Keterampilan Sosial Dalam Pembelajaran Inkuiri Pada IPA di SMP. Seminar Nasional Pendidikan Sains. Hal 319-329. Surakarta: Magister Pendidikan Sains dan Doktor IPA FKIP UNS.

Zubaidah, S. 2016. Keterampilan Abad Ke21: Keterampilan yang Diajarkan Melalui Pembelajaran, (10 Desember 2016). Confrence Paper. Hal 1-17. Kalimantan Barat: Program Studi Pendidikan Biologi STKIP Persada Khatulistiwa Sintang. 